\title{
The socioeconomic and environmental drivers of the COVID-19 pandemic: A review
}

\author{
Tong Wu ii
}

Received: 13 July 2020/Revised: 20 November 2020/Accepted: 28 December 2020/Published online: 28 January 2021

\begin{abstract}
In recent decades, there has been an intensification of the socioeconomic and environmental drivers of pandemics, including ecosystem conversion, meat consumption, urbanization, and connectivity among cities and countries. This paper reviews how these four systemic drivers help explain the dynamics of the COVID-19 pandemic and other recent emerging infectious diseases, and the policies that can be adopted to mitigate their risks. Land-use change and meat consumption increase the likelihood of pathogen spillover from animals to people. The risk that such zoonotic outbreaks will then spread to become pandemics is magnified by growing urban populations and the networks of trade and travel within and among countries. Zoonotic spillover can be mitigated through habitat protection and restrictions on the wildlife trade. Containing infectious disease spread requires a high degree of coordination among institutions across geographic jurisdictions and economic sectors, all backed by international investment and cooperation.
\end{abstract}

Keywords Biodiversity conservation - COVID-19 . Emerging infectious diseases - Global health · Pandemics . Wildlife trade

\section{INTRODUCTION}

The first case of COVID-19 (caused by the novel coronavirus SARS-CoV-2) was detected in the city of Wuhan in November 2019 (the exact geographic origin of the disease has not yet been established, and the virus may have been in circulation in other places prior to its detection in Wuhan). It began spreading across China shortly thereafter, and within several months was also detected in a growing number of other countries. By March, the World Health
Organization (WHO) officially declared it a pandemic, or an epidemic with sustained transmission on multiple continents. Initially, the outbreak evoked harrowing memories of the 2002-2003 SARS crisis, which was also caused by a novel coronavirus. But with the pathogen's rapid global spread and deep alterations of social life, it soon became clear that COVID-19 was even more consequential, and indeed would become the worst pandemic in over a century.

There has been a significant increase in the frequency and biological diversity of emerging infectious diseases since the late twentieth century (Smith et al. 2014). There have been several zoonotic outbreaks of global impact in just the past two decades (Fig. 1). In the wake of the COVID-19 outbreak, scholars have called for the explicit inclusion of pandemic risk into the sustainable development agenda (Di Marco et al. 2020). The probability that a zoonotic pathogen will spillover from wildlife into livestock and human populations, as well as the scale of subsequent spread, are conditioned by a variety of socioeconomic and environmental factors. These include faunal abundance and diversity, climatic conditions, livestock production systems, human population distribution and densities, and the networks of trade and travel that connect populations. In China and other rapidly developing economies, changes in these systemic drivers of emerging infectious diseases (EIDs) have been particularly acute (Wu et al. 2017; Munster et al. 2018).

There has been an outpouring of studies in response to COVID-19, with most of this research focusing on the disease's microbiological, genetic, and medical dimensions. But the pandemic's unprecedented scale and severity should also throw light on the importance of macro-level determinants of infectious disease risk (Morens and Fauci 2020). This paper synthesizes the relevant interdisciplinary 
Ebola Virus Disease

Outbreak Years: 2014-2016

Human Cases: >28,600 (confirmed)
COVID-19 (Pandemic)

Outbreak Years: 2019-present Human Cases: >74 million (confirmed)
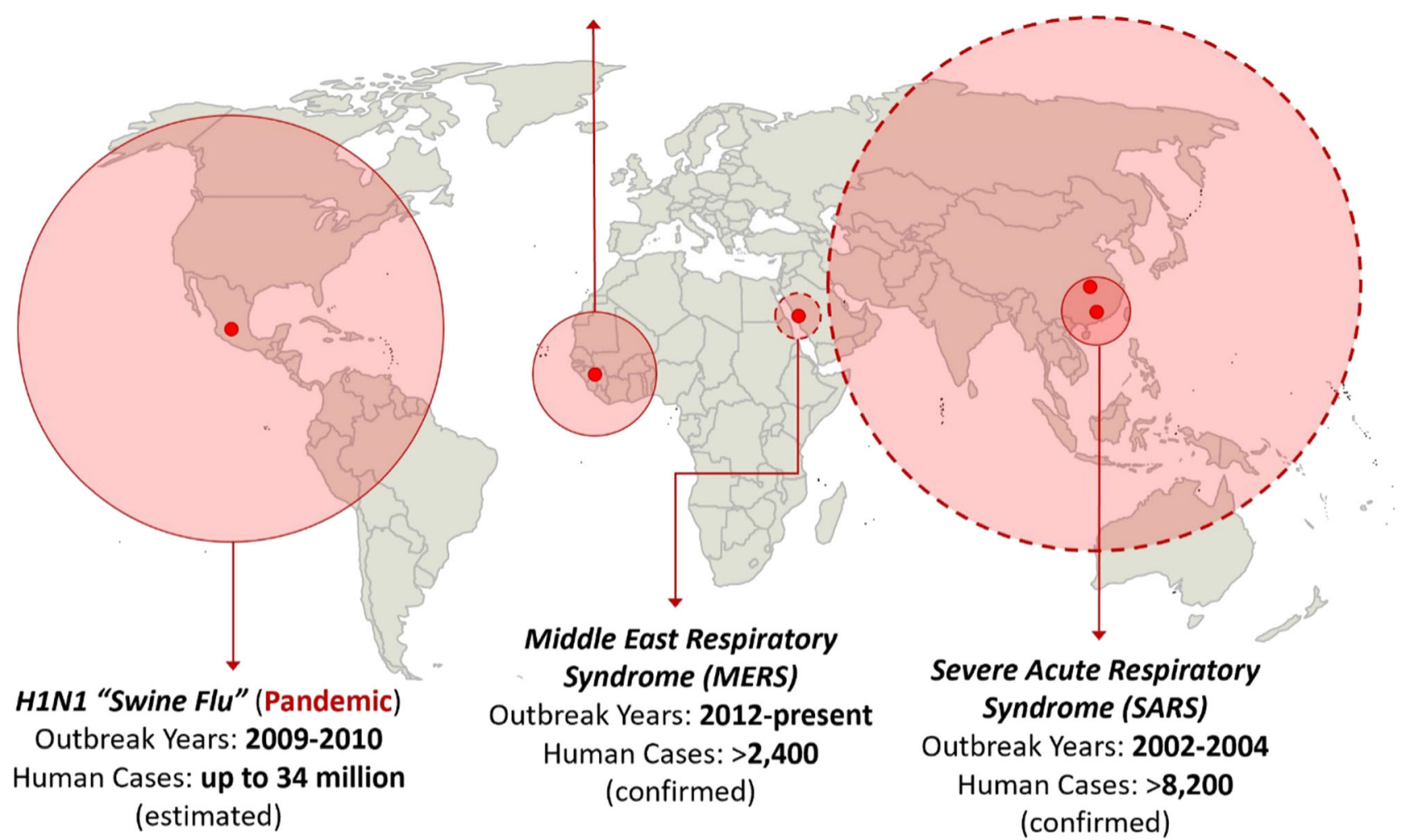

i


epidemiological fault lines, socioeconomic and environmental changes have exacerbated the likelihood and impacts of outbreaks (Fig. 2).

\section{Ecosystem conversion, meat consumption, and pathogen spillover risks}

The large majority of emerging and re-emerging infectious diseases are zoonotic-that is, they derive from animal hosts (Taylor et al. 2001). The existing scientific evidence points to SARS-CoV-2 as originating in bats (order Chiroptera), with spillover into human populations through an intermediate species, possibly in a wet market (i.e., traditional markets selling live or freshly slaughtered animals) (Wang et al. 2020; Zhou et al. 2020). Bats account for approximately one quarter of all mammalian species, are widely distributed across the world, and many readily adapt to human- and livestock-dominated landscapes (Plowright et al. 2011; Lim et al. 2018). While this allows bats to provide valuable ecosystem services such as pest control and pollination (Boyles et al. 2011), they can also pose a threat to livestock and human health because they host a wide range of viruses. In southern China and Southeast Asia, numerous coronaviruses have been serologically detected among people who live near bat habitats; this suggests that interspecies infections at the wildlife- livestock-human nexus occur frequently across the region (Ge et al. 2013; Wang et al. 2018; Li et al. 2019).

The conversion of ecosystems, particularly through deforestation, agricultural intensification, and urbanization, increases the probability of interspecies transmission by expanding the interface of contact between wildlife, livestock, and people at the landscape scale (Brearley et al. 2013; Jones et al. 2013; Murray and Daszak 2013; Myers et al. 2013; Rohr et al. 2019; Bloomfield et al. 2020; Gibb et al. 2020; Lambin et al. 2020; Pulliam et al. 2012). Furthermore, in such highly impacted landscapes, climate change is likely to exacerbate spillover risks (Albery et al. 2020; Vandegrift et al. 2010) (climate change is itself driven by greenhouse gas emissions from deforestation and livestock growth, a fact that has been used to argue for societal shifts to less meat-intensive diets Stehfest et al. 2009). For instance, it has been found that warmer temperatures prompt bats to leave forests for agricultural areas, where they are more likely to encounter livestock and people and therefore spread disease (Looi and Chua 2007). Additionally, climate change may expand the habitat range of bats and thereby increase the range of pathogens they carry (Martin et al. 2018).

In conjunction with ecosystem conversion, the human consumption of animal protein increases spillover risks (Rohr et al. 2019). Across the world, growing meat

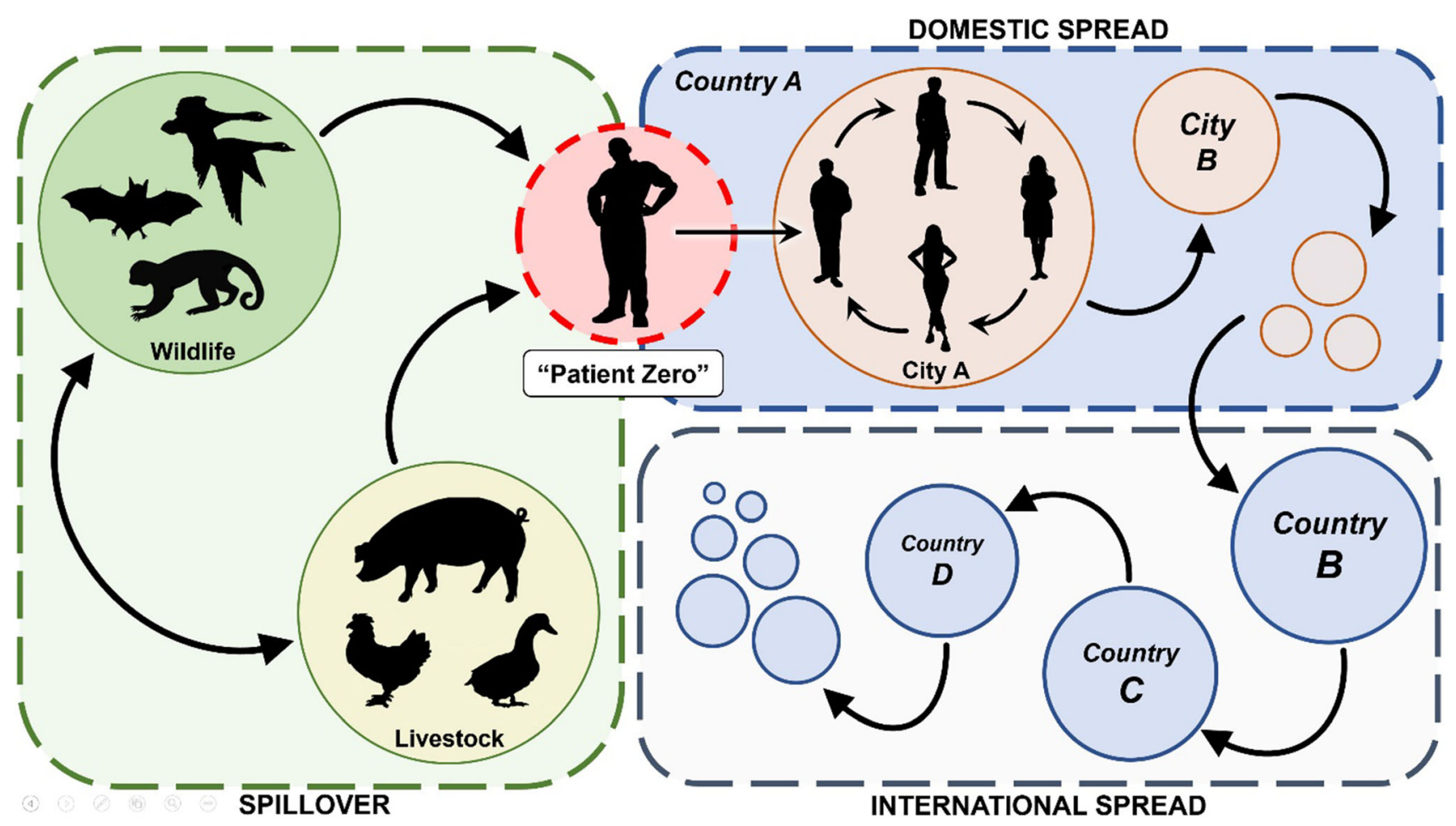

Fig. 2 The anatomy of a pandemic: from pathogen spillover at the wildlife-livestock-human nexus to human-to-human transmission within cities, between cities, and across countries 
consumption has led to a dramatic growth in livestock populations (Fig. 3), which often serve as a staging post for pathogens to infect people. For instance, nearly all confirmed human infections of HPAI (highly pathogenic avian influenza) H5N1 and H7N9 have been from poultry, and pigs can also serve as intermediate sources of zoonotic transmission for influenza and other viruses (Lai et al. 2016; Wang et al. 2017). The rising demand for meat has also included wild species. In Asia, Africa, and Latin America, this has fueled an extensive and often illicit trade in wildlife and their products, adding further incentive to the encroachment of natural ecosystems for farming, hunting, and trafficking (Nathan et al. 2005; Brashares et al. 2011; Challender et al. 2019). Such agro-ecological changes are major drivers of zoonotic emergence and reemergence globally (Pulliam et al. 2012; Jones et al. 2013; Myers et al. 2013; Rohr et al. 2019).

If human-altered landscapes are the primary interface of contact between livestock and wildlife, then wet markets are a frequent venue of human exposure to novel infections. Wet markets are widespread throughout Asia, Africa, and Latin America, anchoring trade networks for livestock and wildlife (Zhang et al. 2008; Smith et al. 2009; Wu and Perrings 2018). They are convergence points for animals from diverse locations, carrying potentially diverse pathogens, and their micro-ecological conditions are often characterized by congestion and lack of running water. In China and Southeast Asia, wet markets pose particularly high risks of avian influenza and other zoonotic infections (Webster 2004; Woo et al. 2006). Similarly, in places such as western Africa and South Asia, bushmeat sold in both rural and urban markets are a major source of dietary protein but have also led to infections by Ebola and Hendra virus, among other pathogens (Nathan et al. 2005; OrdazNemeth et al. 2017; Nahar et al. 2020).

Supermarkets, with their frozen and processed meat products, have significantly lower risks of zoonotic transmission. Nonetheless, they have not become "mainstream" in many parts of the world despite economic modernization. For instance, wet markets remain a primary source of meat purchases across much of Asia and Africa (East et al. 2005; Zhang et al. 2008; Sheherazade and Tsang 2015). China has attempted to promote a "wet market-to-supermarket" transition since at least 2002, but progress has
Tree Cover Loss

(accumulated \% of total forest cover in 2000)

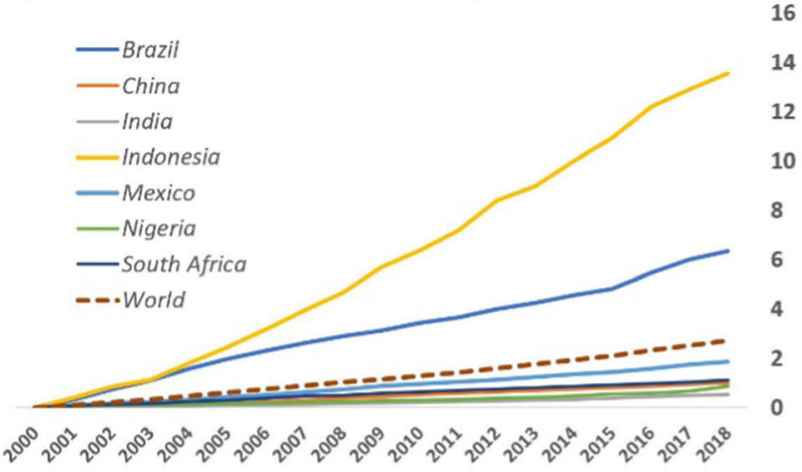

Live animal stocks

(\% of 2000 level in total heads)

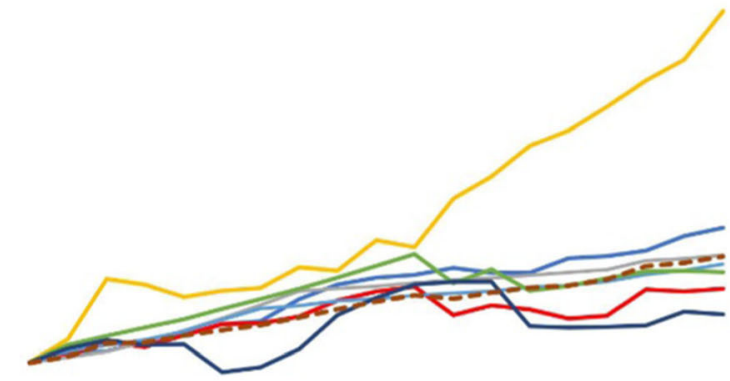

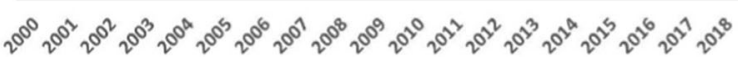

Cropland

(\% of 2000 land cover)

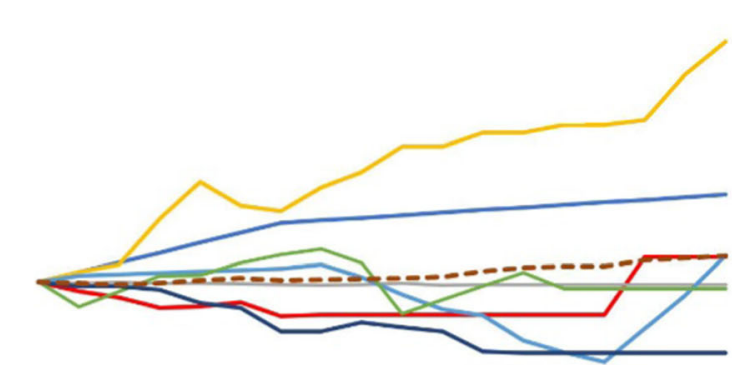

150

140

130

120

110

100

90

80

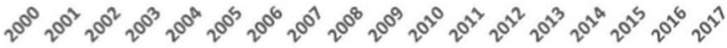

Meat consumption

(\% of 2000 level in $\mathrm{kg} /$ person/year)

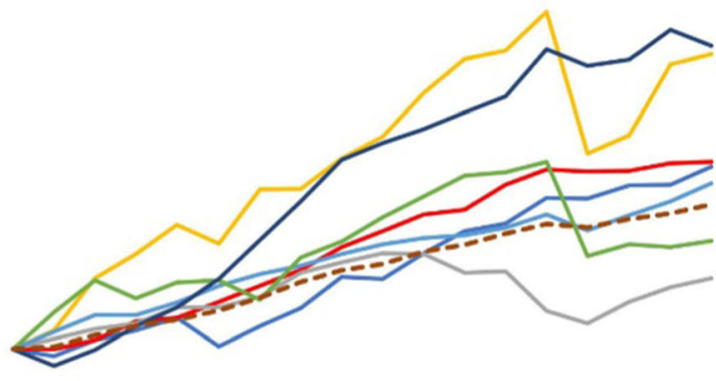

200

190

180

170

160

150

140

130

120

110

100

90

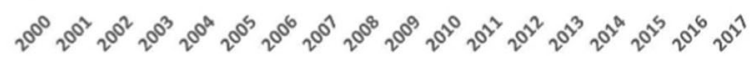

Fig. 3 Trends in selected socioeconomic and environmental risk factors of disease spillover for major emerging economies and the world, 2000-2018. Sources Global Forest Watch (https://data.globalforestwatch.org/); Food and Agriculture Organization (http://www.fao.org/faostat/ en/) 
been slow (Maruyama et al. 2016). Even in the high-income metropolis of Shanghai, approximately 120 million out of the 190 million poultry purchased in 2013 - the year of the HPAI H7N9 outbreak-were from live bird markets (Pi et al. 2014). And even in the wake of the West African Ebola Epidemic of 2014-2015, a study of local communities found that demand for bushmeat was less elastic in wealthier households than in poorer ones (Ordaz-Nemeth et al. 2017). The persistence of wet markets in many parts of the world will mean that for the foreseeable future, higher incomes will mean higher demand for higher-risk animal protein (East et al. 2005; Brashares et al. 2011).

\section{Concentration, connectivity, and the spread of infectious disease}

As landscape change and increasing meat consumption lead to higher spillover risks, the growth of urban concentration and connectivity means that pathogens, once ensconced in human or livestock populations, will be propagated farther and faster (Alirol et al. 2011) (Fig. 4). For instance, in just the 17 years after the 2002 SARS

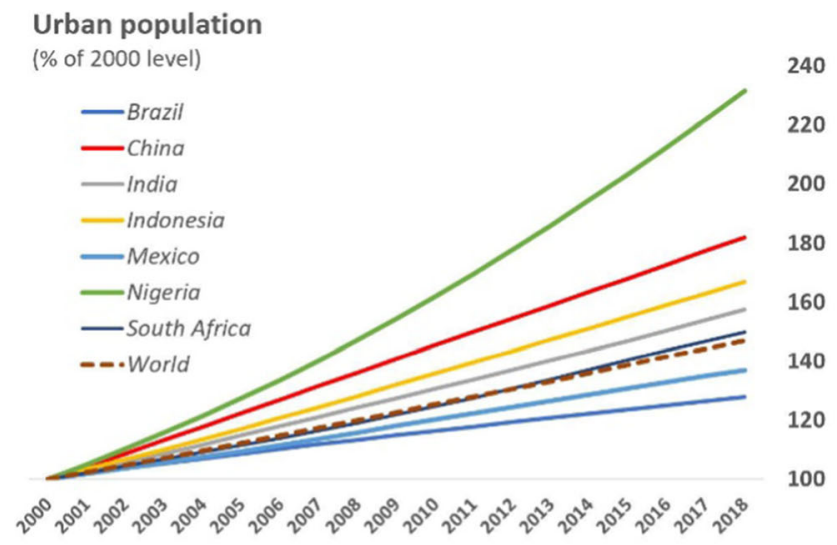

Air travel passengers

(\% of 2000 level)

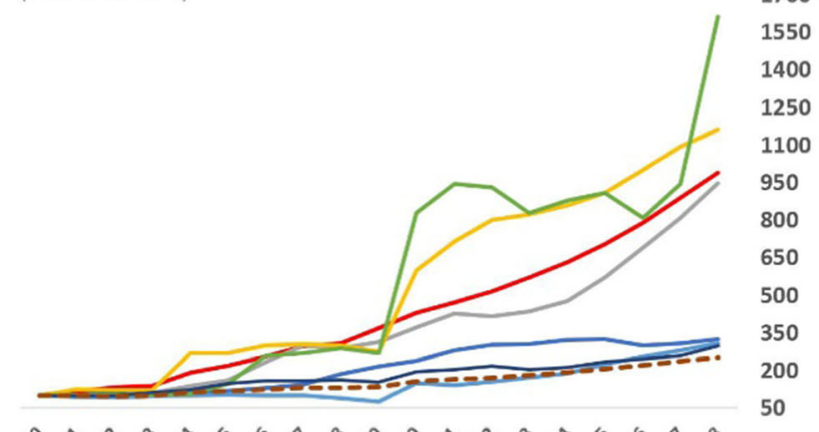

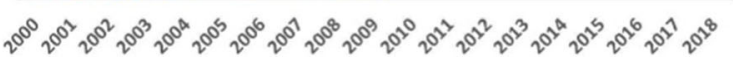

outbreak, China's urban population grew by over 350 million people, taking its share of the total population from 38.4 to $60.3 \%$ (World Bank 2020). Although exemplary in scale, China's urbanization is part and parcel of a global trend: the world as a whole has added over 1.2 thousand million city dwellers since 2002 , with approximately $88 \%$ occurring in low- and middle-income economies (World Bank 2020). A higher population concentration is likely to amplify outbreaks-as was seen when SARS struck the dense urban centers of the Pearl River Delta (Patel and Burke 2009). This urban amplification effect is likely to have also exacerbated the COVID-19 outbreak in Wuhan, which experienced a growth of over 1.6 million permanent residents in the 5 years from 2015 to 2019 (for a total of over 11.2 million) (Wuhan Bureau of Statistics 2020).

As urban regions across the world became epicenters of COVID-19 transmission, the difficulty of sustaining social distancing and other containment measures in densely populated settings became clear. Infection risks due to urban crowding can also be exacerbated by aspects of the built environment, particularly in the large and growing cities of the Global South. Urban centers such as Mumbai,

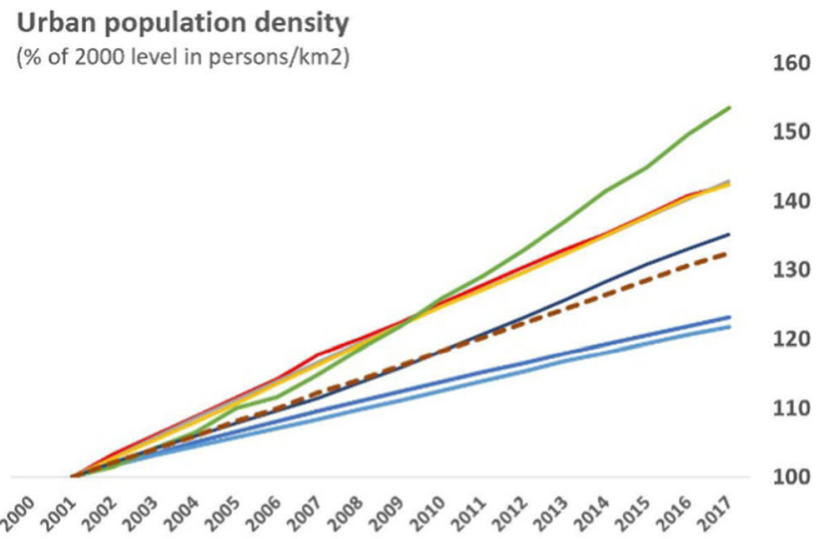

Global livestock trade (\% of 2000 level) 500

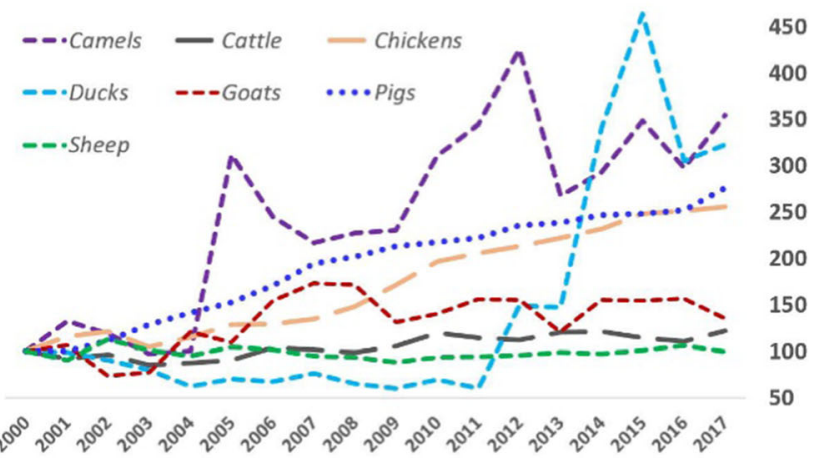

Fig. 4 Trends in selected socioeconomic and environmental risk factors of domestic and international disease spread for major emerging economies and the world, 2000-2018. Sources The World Bank (https://data.worldbank.org/); Food and Agriculture Organization (http://www. fao.org/faostat/en/) 
Rio de Janeiro, Jakarta, and Johannesburg have large networks of informal settlements or "slums." In these neighborhoods, the probability of human-to-human transmission in dense living quarters is increased by poor sanitation and weak infrastructure (Snyder et al. 2014; Corburn et al. 2020). Additionally, the greater prevalence of other diseases among the urban poor, whether communicable ones such as tuberculosis and HIV/AIDS or noncommunicable ones such as cancer, significantly increase comorbidity risks (Weiss and McMichael 2004).

The growth of urban populations is often accompanied by large-scale infrastructure construction. This has been most pronounced in China, where the length of China's railways more than doubled, and that of its highways nearly trebled, between 2000 and 2018 (National Bureau of Statistics of China 2020). Prompted by rising consumer demand, these new pathways have facilitated a rapidly growing cross-country trade in livestock and wildlife (Zhang et al. 2008; Wu et al. 2017). Rising incomes have also coupled with new transportation networks to create a large class of travelers: in China, domestic tourism as measured in person times increased from 744 million to nearly 5.54 thousand million between 2000 and 2018 (National Bureau of Statistics of China 2020). COVID-19's infectiousness is a function of the biological properties of SARS-CoV-2 itself; but like all other pathogens, its spread is also determined by networks of trade and travel (Tatem et al. 2006; Perrings et al. 2018). Wuhan has long been an important entrepot bestriding the Yangtze River, is the hub of several cross-country railway lines, and ranks among the top Chinese cities for transport connectivity (Zhu et al. 2018). That this well-connected "megacity" (a city with a population exceeding 10 million people) was the first epicenter of the COVID-19 pandemic undoubtedly played a role in the speed with which infections reached the rest of the country.

The world's growing urban hubs have also become crucial nodes of international trade and travel. Such networks have expanded the ranges of many pathogens, whether those borne by commodities (mostly animals and animal products), by vectors such as mosquitoes, or by people (Hosseini et al. 2010; Alirol et al. 2011; Perrings et al. 2018). The globalization of China's economy has meant a greater capacity to project infectious diseases as well as greater exposure to them (Wu et al. 2017). Compared to SARS-CoV, which reached 29 countries in 2002-2004, SARS-CoV-2's much more rapid and extensive international dispersal, with cases being reported in over 200 countries and territories within 1 year of first detection, has likely been driven by the global growth of urbanization and trade and travel during the intervening period.

\section{MITIGATING THE SOCIOECONOMIC AND ENVIRONMENTAL DRIVERS OF PANDEMICS}

Although there have been advances in medical treatments and other aspects of epidemic control in China and elsewhere, these improvements have had to race against the intensification of EID risks described above (Gong et al. 2012; Zhang et al. 2017). And with respect to COVID-19 at least, the evidence strongly suggests that the latter has outstripped the former, particularly at the global level. Consequently, policies need to adapt to these systemic changes. At the very least, policymakers must supplement, and in some cases replace, ad hoc and reactive strategies with ones that preemptively address socioeconomic and environmental drivers (Pike et al. 2014; Di Marco et al. 2020; Dobson et al. 2020). In particular, mitigating global pandemic risks requires in situ and ex situ biodiversity conservation and institutional coordination across geographic jurisdictions and economic sectors-all within a robust framework of international investment and cooperation.

\section{Biodiversity conservation to prevent interspecies transmission}

The culling of livestock that has been exposed to infectious disease is a long-established control strategy. Over the past two decades, hundreds of millions of poultry, swine, sheep, and cattle have been slaughtered across the world in response to avian influenza, foot-and-mouth disease, swine fever, and other epizootic and zoonotic outbreaks. The economic costs of such draconian measures have been steep, with the loss of valuable livestock compounded by employment impacts and knock-on market effects for other products (FAO 2016). The culling of wildlife is less common, given well-founded conservation concerns, although the COVID-19 pandemic has prompted the culling of millions of captive minks in Europe due to concerns over viral mutation and the threat of human infection. When wildlife culling has been practiced-for instance with respect to bats, wild pigs, and wild ungulatestransmission risks are often magnified due to the alterations of pathogen ecology and evolution (Sokolow et al. 2019). In contrast, biodiversity conservation is likely to be a more ethical and effective form of ecological intervention to mitigate interspecies transmission.

In situ biodiversity conservation through habitat protection can create an epidemiological separation between wildlife reservoirs and the livestock populations to which corresponding pathogens can be transmitted. For instance, it has been found that protecting lakes and wetlands can reduce the probability of avian influenza being transmitted 
to poultry by wild waterfowl (Wu et al. 2020). Protected areas can keep livestock outside of areas with wild disease reservoirs. At the same time, migratory birds prefer natural habitats to human-dominated ones, and in the absence of the former, they are often displaced to agricultural areas populated by livestock and people (Bonter et al. 2009; Li et al. 2013). This dynamic could hold for pathogen dynamics at other wildlife-livestock interfaces (as mentioned earlier, the loss of natural habitat and changing climates can displace bats into farmlands). Therefore, protecting forests, wetlands, and other ecosystem types could be an effective means of mitigating interspecies transmission.

Ex situ biodiversity conservation through the strict regulation or even abolition of the wildlife trade could also reduce interspecies transmission risks. In the wake of the COVID-19 outbreak, China's government announced an indefinite ban on the wildlife trade. Such a prohibition was also enacted during the SARS crisis in 2003, and wet markets in affected regions were shuttered following the 2013 H7N9 outbreak, but in both cases, commercial activities resumed once the associated epidemics subsided. For such stringent regulations to be sustainable, they will have to address the large financial incentives and vested interests involved. In 2016, the wildlife trade in China was estimated to be worth over 520 thousand million CNY (approximately 7.49 thousand million USD at the year-end exchange rate) and employed approximately 14 million people (Chinese Academy of Engineering 2016). Finding alternative employment for the many people working in the wildlife trade would be prudent social policy, as well as a way to prevent this lucrative business from being driven underground, which would make disease surveillance and post-outbreak containment even more difficult. China's continued urbanization, while increasing infectious disease risks in other ways, may provide opportunities for transitioning employment away from the wildlife trade (at least on the supply side) by drawing rural labor into alternative professions.

This policy logic should also be upscaled to the global level, where control of the wildlife trade has been a cornerstone of biodiversity conservation efforts (Phelps et al. 2010). Internationally, the wildlife trade has been implicated in the spread of numerous infectious diseases across countries (Pavlin et al. 2009; Smith et al. 2009). The Convention on International Trade in Endangered Species of Wild Fauna and Flora (CITES), administered by the United Nations Environment Programme (UNEP), is the most comprehensive global agreement of its kind. Since 2015, it has partnered with the World Animal Health Organization (OIE) to integrate policies on controlling animal diseases with efforts to curb cross-border wildlife trafficking (Karesh et al. 2016). In the coming years, the
Convention on Biodiversity (CBD), also administered by UNEP, will seek to enact a new and more effective framework for biodiversity protection (none of the CBD's Aichi Biodiversity Targets for 2010-2020 were fully met). Aligning conservation imperatives with the needs of global health could provide fresh impetus for progress in both agendas. This synergy, whether realized through habitat protection or wildlife trade restrictions, has been endorsed by the United Nations' International Platform on Biodiversity and Ecosystem Services (IPBES) in the wake of the COVID-19 pandemic (Daszak et al. 2020).

Livestock and human populations are likely to continue growing for the foreseeable future. Preventing their exposure to wild disease reservoirs will greatly reduce the likelihood of EID spillover. Indeed, reducing contact between wild disease reservoirs on the one hand and livestock and people on the other is crucial, constituting an early intervention in the chain of transmission that eventuates in pandemics (Fig. 2). Even when a zoonotic outbreak does not initially result in sustained human-to-human transmission, as has been the case with most zoonoses, they can evolve that ability later on. For instance, it is possible that $\mathrm{H} 5 \mathrm{~N} 1$ and $\mathrm{H} 7 \mathrm{~N} 9$ could eventually acquire, through genetic reassortment or mutation, sustained human-to-human transmissibility and thereby cause influenza pandemics (Fuller et al. 2013; Peng et al. 2014).

\section{Institutional coordination to mitigate infectious disease spread}

As discussed above, vast socioeconomic and environmental changes have caused infectious diseases to become increasingly transboundary and multi-sector problems (Young et al. 2006; DeWitte et al. 2016). Because they can be borne by animals, commodities, and people, pathogens routinely disperse across administrative boundaries. And as the COVID-19 pandemic has shown, a city or country is unlikely to remain disease free if infections persist in surrounding areas. Furthermore, mitigating pathogen spillover at the wildlife-livestock-human nexus involves agricultural as well as ecological management, and curtailing infectious disease spread involves customs as well as law enforcement, among other agencies. Therefore, a high degree of coordination among institutions with varying geographical jurisdictions and responsible for different economic sectors is needed.

At the national level, the realization of such institutional coordination depends on the socioeconomic and environmental conditions particular to a given country- "onesize-fits-all" solutions are unlikely (Young et al. 2006; Perrings 2007). In China, for instance, translating central government directives into consistent local implementation has been a besetting challenge (Qi and Zhang 2014). 
Despite progress in recent years, enforcing policies such as wildlife trade restrictions could encounter bureaucratic obstacles as well as resistance for cultural and financial reasons (Roe et al. 2020). To improve responsiveness to infectious disease outbreaks by coordinating across jurisdictional (e.g., different city and provincial governments) and sectoral barriers, the head of China's COVID-19 task force recommended that the country's Center for Disease Control and Prevention (China CDC) be given greater administrative powers, allowing it to report directly to central authorities and issue public warnings (Wu 2020b).

At the international level, processes of globalization have greatly increased the speed and scope of infectious disease spread across national boundaries. The rapid dissemination of scientific findings is key to the development of vaccines, diagnostics, and epidemiological forecasting. This means that international institutions need to coordinate the distribution of information and resources more effectively, as well as standardize management protocols (Young et al. 2006). The WHO and allied institutions within the UN system remain best suited for this role. And to address the socioeconomic and environmental drivers of EIDs systematically, cross-sectoral collaborations between the WHO and organizations such as the Food and Agriculture Organization (FAO) and the OIE should be strengthened. A salient example of such a collaboration is the Global Animal Disease Information System (administered by the FAO's Emergency Prevention System), which provides up-to-date and location-specific outbreak information on a wide range of diseases known to infect wildlife, livestock, and people (http://empres-i.fao.org/eipws3g/).

Strong biosecurity at trade and travel checkpoints (i.e., "infectious disease firebreaks") could decrease the transboundary dispersal of pathogens (Wallace and Fitch 2008; $\mathrm{Wu}$ and Perrings 2018). Therefore, international agreements that elevate and standardize such biosecurity protocols are essential to mitigating cross-border pathogen spread. For instance, the Agreement on the Application of Sanitary and Phytosanitary Measures (SPS Agreement) regulates biosecurity standards of World Trade Organization (WTO) member states, with the aim of protecting human and animal health (https://www.wto.org/english/ tratop_e/sps_e/sps_e.htm/). However, the efficacy of such agreements depends on the capacity and compliance of national governments, as well as the resources of the international bodies charged with overseeing them. This makes the strengthening of such multilateral institutions crucial to global health.

However, the COVID-19 pandemic has shown that containing infectious disease spread is much more difficult when the pathogen shows sustained human-to-human transmissibility. In China and Europe during the early phases of the pandemic, massive quarantines and travel restrictions were highly effective. Most notably, the quarantine of Wuhan-which effectively severed the megacity's connectivity to the rest of the country and the worldsignificantly slowed COVID-19's spread, providing valuable time for the adoption of mitigative measures elsewhere (Kraemer et al. 2020). Less ad hoc biosecurity measures, such as regular temperature checks and "disease-free status passports," which have been adopted or mooted in response to COVID-19 could help limit transboundary disease spread in the medium-to-long run. Nonetheless, as the recent pandemic has also shown, stringent restrictions on human mobility and travel, particularly abrupt restrictions such as large-scale quarantines, could cause prohibitively high economic losses as well as abrade ethical and political sensibilities.

Therefore, a preventative approach targeting the drivers of EIDs is likely to be more practical and also preferable from a humanitarian standpoint. As disease ecologist Peter Daszak aptly summarized in response to COVID-19's emergence, global health depends on not "missing the really big picture: Pandemics are on the rise, and we need to contain the process that drives them, not just the individual diseases" (Daszak 2020). And crucial to such a long-term mitigation strategy is international investment and cooperation.

\section{Increasing international investment and cooperation}

International investment in the above-mentioned policies should be commensurate with the scale of pandemic risks. In terms of just its economic impact, COVID-19 precipitated a fall in global gross domestic product at least as steep as that which befell the world during the worst years of the Great Depression (International Monetary Fund 2020). Other human and socials costs could take years if not decades to fully register, with the most onerous burdens likely falling on the most impoverished and vulnerable. These impacts underscore the necessity of pandemic mitigation, if not as a straightforward matter of civic prudence then as a highly valuable form of insurance. Indeed, preemptively targeting the socioeconomic and environmental drivers of EIDs is more economically efficient than posthoc containment, and at the global scale, such investments could be worth several hundred thousand million USD over the coming century (Pike et al. 2014).

These high economic values could be institutionalized in the form of "pandemic funds" (Berry et al. 2018), financed through levies on high-risk activities such as habitat destruction and the wildlife trade (Daszak et al. 2020). Useful investments surely include vaccine development and distribution, but such funds could also finance employment re-training for those involved in the wildlife trade, the strengthening of protected area management, and 
better surveillance of livestock and wild disease reservoirs. An international pandemic fund would be essential for financing such efforts in lower-income countries. Furthermore, given the global public goods nature of pandemic prevention, such a fund would ideally be placed under the auspices of the UN system and/or other multilateral organizations.

However, providing sufficient investment and empowering the relevant institutions to utilize it depend on international cooperation. In this respect, the geopolitical developments surrounding COVID-19 have not been encouraging. In particular, while cooperation between the US and China is essential to effective action on global health (Smiley Evans et al. 2020), the two countries' relationship has been characterized by growing competition and even animosity in recent years. One specific manifestation of this diplomatic deterioration was the US government's decision to withdraw its embedded expert and representative at China CDC in 2018. This role was meant to facilitate communication between the two countries and improve pandemic preparedness. It is not difficult to imagine why its services would have been useful during the COVID-19 outbreak in Wuhan 1 year later.

Additionally, in order for the WHO and allied institutions to remain effective stewards of global health, they need the robust support (financially and otherwise) of the international community-above all of major economies such as the US, China, and the EU. However, in the early phase of the pandemic, the US government withdrew funding from the WHO, which was already operating with a budget incommensurately small compared to the global scale of its responsibilities (at US\$ 2.4 thousand million in 2020 , it was approximately the same size as the budget of a large American hospital Huang 2020). The Lancet's editorin-chief characterized this decision as a "crime against humanity" (Horton 2020). As secular global trends, the intensification of the socioeconomic and environmental drivers of EIDs will not await the settling of geopolitical squabbles. If the world is to have a chance at effectively mitigating pandemic risks, the current fracturing of international cooperation needs to be quickly reversed ( $\mathrm{Wu}$ 2020a).

\section{CONCLUDING REMARKS}

In 1969, the US Surgeon General, the country's leading public health official, proclaimed that it was "time to close the book on infectious disease as a major health threat" (Armelagos et al. 2005). This confident belief was premised on the idea that the world had undergone an "epidemiological transition" in which economic modernization made infectious diseases an ever-smaller risk to public health (McKeown 2009; Santosa et al. 2014). COVID-19 and the broader trend in the rising frequency and impact of EIDs suggest that economic modernization has indeed spurred an epidemiological transition-just not in the direction the Surgeon General had expected.

Many lessons can be drawn from global efforts to combat COVID-19. For instance, it has been shown that social distancing and quarantines may be needed in the immediate aftermath of an outbreak. For the medium term, the development of therapeutics and vaccines has also been a key policy focus, and there have even been renewed calls for panviral medicines that target a range of pathogens. But as recent experience has also made apparent, ad hoc "lockdown" policies carry significant social and financial costs, making them emergency measures, not long-term solutions. Whether medical advances can keep pace with the emergence of novel pathogens or be distributed in ways that create timely population-level immunity remains highly uncertain. While these short- and medium-term policies will still undoubtedly be necessary, national governments and international institutions over the long run also need to focus on mitigating the socioeconomic and environmental drivers of EIDs. As this paper has sought to show, unless these systemic factors are addressed, the world could be threatened by more pandemics for generations to come.

Acknowledgements I would like to thank Dr. Jeffrey McNeely and two anonymous reviewers for their comments and suggestions, which have greatly improved the quality of this paper.

\section{REFERENCES}

Albery, G.F., E.A. Eskew, N. Ross, and K.J. Olival. 2020. Predicting the global mammalian viral sharing network using phylogeography. Nature Communications 11: 2260.

Alirol, E., L. Getaz, B. Stoll, F. Chappuis, and L. Loutan. 2011. Urbanisation and infectious diseases in a globalised world. The Lancet Infectious Diseases 11: 131-141.

Allen, T., K.A. Murray, C. Zambrana-Torrelio, S.S. Morse, C. Rondinini,M. Di Marco, N. Breit, K.J. Oliva, et al. 2017. Global hotspots and correlates of emerging zoonotic diseases. Nature Communications 8: 1124.

Armelagos, G.J., P.J. Brown, and B. Turner. 2005. Evolutionary, historical and political economic perspectives on health and disease. Social Science and Medicine 61: 755-765.

Berry, K., T. Allen, R.D. Horan, J.F. Shogren, D. Finnoff, and P. Daszak. 2018. The economic case for a pandemic fund. EcoHealth 15: 244-258.

Bloomfield, L.S.P., T.L. McIntosh, and E.F. Lambin. 2020. Habitat fragmentation, livelihood behaviors, and contact between people and nonhuman primates in Africa. Landscape Ecology 35: 985-1000.

Bonter, D.N., S.A. Gauthreaux Jr., and T.M. Donovan. 2009. Characteristics of important stopover locations for migrating birds: Remote sensing with radar in the Great Lakes Basin. Conservation Biology 23: 440-448. 
Boyles, J.G., P.M. Cryan, G.F. McCracken, and T.H. Kunz. 2011. Economic importance of bats in agriculture. Science 332: 41-42.

Brashares, J.S., C.D. Golden, K.Z. Weinbaum, C.B. Barrett, and G.V. Okello. 2011. Economic and geographic drivers of wildlife consumption in rural Africa. Proceedings of the National Academy of Sciences of USA 108: 13931-13936.

Brearley, G., J. Rhodes, A. Bradley, G. Baxter, L. Seabrook, D. Lunney, Y. Liu, and C. McAlpine. 2013. Wildlife disease prevalence in human-modified landscapes. Biological Reviews 88: 427-442.

Challender, D.W.S., A. Hinsley, and E.J. Milner-Gulland. 2019. Inadequacies in establishing CITES trade bans. Frontiers in Ecology and the Environment 17: 199-200.

Chinese Academy of Engineering. 2016. A sustainable development strategy for China's wildlife industry. Beijing: Chinese Academy of Engineering.

Corburn, J., D. Vlahov, B. Mberu, L. Riley, W.T. Caiaffa, S.F. Rashid, A. Ko, S. Patel, et al. 2020. Slum health: Arresting COVID-19 and improving well-being in urban informal settlements. Journal of Urban Health 97: 348-357.

Daszak, P. 2020. We knew disease X was coming. It's here now. The New York Times.

Daszak, P., C. das Neves, J. Amuasi, D. Hayman, T. Kuiken, B. Roche, C. Zambrana-Torrelio, P. Buss, et al. 2020. IPBES (2020) Workshop Report on Biodiversity and Pandemics of the Intergovernmental Platform on Biodiversity and Ecosystem Services. Bonn: IPBES Secretariat.

DeWitte, S.N., M.H. Kurth, C.R. Allen, and I. Linkov. 2016. Disease epidemics: Lessons for resilience in an increasingly connected world. Journal of Public Health 39: 254-257.

Di Marco, M., M.L. Baker, P. Daszak, P. De Barro, E.A. Eskew, C.M. Godde, T.D. Harwood, M. Herrero, et al. 2020. Opinion: Sustainable development must account for pandemic risk. Proceedings of the National Academy of Sciences of USA 117: 3888-3892.

Dobson, A.P., S.L. Pimm, L. Hannah, L. Kaufman, J.A. Ahumada, A.W. Ando, A. Bernstein, J. Busch, et al. 2020. Ecology and economics for pandemic prevention. Science 369: 379-381.

East, T., N. Kümpel, E. Milner-Gulland, and M. Rowcliffe. 2005. Determinants of urban bushmeat consumption in Río Muni, Equatorial Guinea. Biological Conservation 126: 206-215.

FAO. 2016. Economic analysis of animal diseases. FAO Animal Production and Health Guidelines, 18. Rome: Food and Agricultural Organization of the United Nations.

Fuller, T.L., M. Gilbert, V. Martin, J. Cappelle, P. Hosseini, K.Y. Njabo, S.A. Aziz, X. Xiao, et al. 2013. Predicting hotspots for influenza virus reassortment. Emerging Infectious Diseases 19: $581-588$

Ge, X.-Y., J.-L. Li, X.-L. Yang, A.A. Chmura, G. Zhu, J.H. Epstein, J.K. Mazet, B. Hu, et al. 2013. Isolation and characterization of a bat SARS-like coronavirus that uses the ACE2 receptor. Nature 503: 535-538.

Gibb, R., D.W. Redding, K.Q. Chin, C.A. Donnelly, T.M. Blackburn, T. Newbold, and K.E. Jones. 2020. Zoonotic host diversity increases in human-dominated ecosystems. Nature 584: 398-402.

Gong, P., S. Liang, E.J. Carlton, Q. Jiang, J. Wu, L. Wang, and J.V. Remais. 2012. Urbanisation and health in China. The Lancet 379: 843-852.

Horton, R. 2020. Offline: Why President Trump is wrong about WHO. The Lancet 395: 1330.

Hosseini, P., S.H. Sokolow, K.J. Vandegrift, A.M. Kilpatrick, and P. Daszak. 2010. Predictive power of air travel and socio-economic data for early pandemic spread. PLOS ONE 5: e12763.

Huang, P. 2020. Trump and WHO: how much does the U.S. give? What's the impact of a halt in funding? National Public Radio. https://www.npr.org/sections/goatsandsoda/2020/04/15/8346661 23/trump-and-who-how-much-does-the-u-s-give-whats-the-impa ct-of-a-halt-in-funding/. Accessed 5 Nov 2020.

International Monetary Fund. 2020. World Economic Outlook, October 2020: A long and difficult ascent. Washington, DC: International Monetary Fund.

Jones, B.A., D. Grace, R. Kock, S. Alonso, J. Rushton, M.Y Said, D. McKeever, F. Mutua, et al. 2013. Zoonosis emergence linked to agricultural intensification and environmental change. Proceedings of the National Academy of Sciences of USA 110: 8399-8404.

Jones, K.E., N.G. Patel, M.A. Levy, A. Storeygard, D. Balk, J.L Gittleman, and P. Daszak. 2008. Global trends in emerging infectious diseases. Nature 451: 990-993.

Karesh, W.B., R. Kock, and C.C. Machalaba. 2016. CITES: In sickness and in health? EcoHealth 13: 441-442.

Kraemer, M.U.G., C.-H. Yang, B. Gutierrez, C.-H. Wu, B. Klein, D.M. Pigott, Open COVID-19 Data Working Group, L. du Plessis, et al. 2020. The effect of human mobility and control measures on the COVID-19 epidemic in China. Science 368: 493-497.

Lai, S., Y. Qin, B. Cowling, X. Ren, N.A. Wardrop, M. Gilbert, T.K. Tsang, P. $\mathrm{Wu}$, et al. 2016. Global epidemiology of avian influenza A H5N1 virus infection in humans, 1997-2015: A systematic review of individual case data. The Lancet Infectious Diseases 16: e108-e118.

Lambin, E.F., A. Tran, S.O. Vanwambeke, C. Linard, and V. Soti. 2020. Pathogenic landscapes: Interactions between land, people, disease vectors, and their animal hosts. International Journal of Health Geographics 9: 54.

Li, D., S. Chen, H. Lloyd, S. Zhu, K. Shan, and Z. Zhang. 2013. The importance of artificial habitats to migratory waterbirds within a natural/artificial wetland mosaic, Yellow River Delta, China. Bird Conservation International 23: 184-198.

Li, H., E. Mendelsohn, C. Zong, W. Zhang, E. Hagan, N. Wang, S. Li, H. Yan, et al. 2019. Human-animal interactions and bat coronavirus spillover potential among rural residents in Southern China. Biosafety and Health 1: 84-90.

Lim, V.-C., E.L. Clare, J.E. Littlefair, R. Ramli, S. Bhassu, and J.-J. Wilson. 2018. Impact of urbanisation and agriculture on the diet of fruit bats. Urban Ecosystems 21: 61-70.

Looi, L.-M., and K.-B. Chua. 2007. Lessons from the Nipah virus outbreak in Malaysia. The Malaysian Journal of Pathology 29: 63-67.

Martin, G., C. Yanez-Arenas, C. Chen, R.K. Plowright, R.J. Webb, and L.F. Skerratt. 2018. Climate change could increase the geographic extent of Hendra virus spillover risk. EcoHealth 15: 509-525.

Maruyama, M., L. Wu, and L. Huang. 2016. The modernization of fresh food retailing in China: The role of consumers. Journal of Retailing and Consumer Services 30: 33-39.

McKeown, R.E. 2009. The epidemiologic transition: Changing patterns of mortality and population dynamics. American Journal of Lifestyle Medicine 3: 19S-26S.

Morens, D.M., and A.S. Fauci. 2020. Emerging pandemic diseases: How we got to COVID-19. Cell 182: 1077-1092.

Munster, V.J., D.G. Bausch, E. de Wit, R.J. Fischer, G. Kobinger, C. Munoz-Fontela, S.H. Olson, S.N. Seifert, et al. 2018. Outbreaks in a rapidly changing Central Africa-Lessons from Ebola. New England Journal of Medicine 379: 1198-1201.

Murray, K.A., and P. Daszak. 2013. Human ecology in pathogenic landscapes: Two hypotheses on how land use change drives viral emergence. Current Opinion in Virology 3: 79-83.

Myers, S.S., L. Gaffikin, C.D. Golden, R.S. Ostfeld, K.H. Redford, T.H. Ricketts, W.R. Turner, and S.A. Osofsky. 2013. Human 
health impacts of ecosystem alteration. Proceedings of the National Academy of Sciences of USA 110: 18753-18760.

Nahar, N., M. Asaduzzaman, U.K. Mandal, N.A. Rimi, E.S. Gurley, M. Rahman, F. Garcia, S. Zimicki, et al. 2020. Hunting bats for human consumption in Bangladesh. EcoHealth 17: 139-151.

Nathan, D.W., D. Peter, A.M. Kilpatrick, and S.B. Donald. 2005. Bushmeat hunting, deforestation, and prediction of zoonotic disease. Emerging Infectious Diseases 11: 1822-1827.

National Bureau of Statistics of China. 2020. China Statistical Yearbook 2019. Beijing: National Bureau of Statistics of China.

Ordaz-Nemeth, I., M. Arandjelovic, L. Boesch, T. Gatiso, T. Grimes, H.S. Kuehl, M. Lormie, C. Stephens, et al. 2017. The socioeconomic drivers of bushmeat consumption during the West African Ebola crisis. PLoS Neglected Tropical Diseases 11: $\mathrm{e} 0005450$.

Patel, R.B., and T.F. Burke. 2009. Urbanization-An emerging humanitarian disaster. New England Journal of Medicine 361: 741-743.

Pavlin, B.I., L.M. Schloegel, and P. Daszak. 2009. Risk of importing zoonotic diseases through wildlife trade, United States. Emerging Infectious Diseases 15: 1721-1726.

Peng, J., H. Yang, H. Jiang, Y. Lin, C.D. Lu, Y. Xu, and J. Zeng. 2014. The origin of novel avian influenza A (H7N9) and mutation dynamics for its human-to-human transmissible capacity. PLOS ONE 9: e93094.

Perrings, C. 2007. Future challenges. Proceedings of the National Academy of Sciences of USA 104: 15179-15180.

Perrings, C., S. Levin, and P. Daszak. 2018. The economics of infectious disease, trade and pandemic risk. EcoHealth 15: 241-243.

Phelps, J., E.L. Webb, D. Bickford, V. Nijman, and N.S. Sodhi. 2010. Boosting CITES. Science 330: 1752-1753.

Pi, C., Z. Rou, and S. Horowitz. 2014. Fair of fowl? Industrialization of poultry production in China. In Global meat complex: The China series, ed. S. Sharma and B. Lilliston. Minneapolis: Institute for Agriculture and Trade Policy.

Pike, J., T. Bogich, S. Elwood, D.C. Finnoff, and P. Daszak. 2014. Economic optimization of a global strategy to address the pandemic threat. Proceedings of the National Academy of Sciences of USA 111: 18519-18523.

Plowright, R.K., P. Foley, H.E. Field, A.P. Dobson, J.E. Foley, P. Eby, and P. Daszak. 2011. Urban habituation, ecological connectivity and epidemic dampening: The emergence of Hendra virus from flying foxes (Pteropus spp.). Proceedings of the Royal Society B: Biological Sciences 278: 3703-3712.

Pulliam, J.R.C., J.H. Epstein, J. Dushoff, S.A. Rahman, M. Bunning, A.A. Jamaluddin, A.D. Hyatt, H.E. Field, et al. 2012. Agricultural intensification, priming for persistence and the emergence of Nipah virus: A lethal bat-borne zoonosis. Journal of the Royal Society Interface 9: 89-101.

Qi, Y., and L. Zhang. 2014. Local environmental enforcement constrained by central-local relations in China. Environmental Policy and Governance 24: 216-232.

Roe, D., A. Dickman, R. Kock, E.J. Milner-Gulland, E. Rihoy, and M. 't Sas-Rolfes. 2020. Beyond banning wildlife trade: COVID-19, conservation and development. World Development 136: 105121.

Rohr, J.R., C.B. Barrett, D.J. Civitello, M.E. Craft, B. Delius, G.A. DeLeo, P.J. Hudson, N. Jouanard, et al. 2019. Emerging human infectious diseases and the links to global food production. Nature Sustainability 2: 445-456.

Santosa, A., S. Wall, E. Fottrell, U. Högberg, and P. Byass. 2014. The development and experience of epidemiological transition theory over four decades: A systematic review. Global Health Action 7: 23574.
Sheherazade, S., and S. Tsang. 2015. Quantifying the bat bushmeat trade in North Sulawesi, Indonesia, with suggestions for conservation action. Global Ecology and Conservation 3: 324-330.

Smiley Evans, T., Z. Shi, M. Boots, W. Liu, K.J. Olival, X. Xiao, S. Vandewoude, H. Brown, et al. 2020. Synergistic China-US ecological research is essential for global emerging infectious disease preparedness. EcoHealth 17: 160-173.

Smith, K.F., M. Behrens, L.M. Schloegel, N. Marano, S. Burgiel, and P. Daszak. 2009. Reducing the risks of the wildlife trade. Science 324: 594-595.

Smith, K.F., M. Goldberg, S. Rosenthal, L. Carlson, J. Chen, C. Chen, and S. Ramachandran. 2014. Global rise in human infectious disease outbreaks. Journal of the Royal Society Interface 11: 20140950.

Snyder, R.E., M.A. Marlow, and L.W. Riley. 2014. Ebola in urban slums: The elephant in the room. The Lancet Global Health 2: e685-e685.

Sokolow, S.H., N. Nova, K.M. Pepin, A.J. Peel, J.R.C. Pulliam, K. Manlove, P.C. Cross, D.J. Becker, et al. 2019. Ecological interventions to prevent and manage zoonotic pathogen spillover. Philosophical Transactions of the Royal Society of London B: Biological Sciences 374: 20180342.

Stehfest, E., L. Bouwman, D.P. van Vuuren, M.G.J. den Elzen, B. Eickhout, and P. Kabat. 2009. Climate benefits of changing diet. Climatic Change 95: 83-102.

Tatem, A.J., D.J. Rogers, and S.I. Hay. 2006. Global transport networks and infectious disease spread. Advances in Parasitology 62: 293-343.

Taylor, L.H., S.M. Latham, and M.E.J. Woolhouse. 2001. Risk factors for human disease emergence. Philosophical Transactions of the Royal Society of London Series B: Biological Sciences 356: 983-989.

Vandegrift, K.J., S.H. Sokolow, P. Daszak, and A.M. Kilpatrick. 2010. Ecology of avian influenza viruses in a changing world. Annals of the New York Academy of Sciences 1195: 113-128.

Wallace, R.G., and W.M. Fitch. 2008. Influenza A H5N1 immigration is filtered out at some international borders. PLOS ONE 3: e1697.

Wang, C., P.W. Horby, F.G. Hayden, and G.F. Gao. 2020. A novel coronavirus outbreak of global health concern. The Lancet 395: 470-473.

Wang, N., S.-Y. Li, X.-L. Yang, H.-M. Huang, Y.-J. Zhang, H. Guo, C.-M. Luo, M. Miller, et al. 2018. Serological evidence of bat SARS-related coronavirus infection in humans, China. Virologica Sinica 33: 104-107.

Wang, X.-L., H. Jiang, P. Wu, T.M. Uyeki, L. Feng, S. Lai, L. Wang, X. Huo, et al. 2017. Epidemiology of avian influenza A H7N9 virus in human beings across five epidemics in mainland China, 2013-17: An epidemiological study of laboratory-confirmed case series. The Lancet Infectious Diseases 17: 822-832.

Webster, R.G. 2004. Wet markets-A continuing source of severe acute respiratory syndrome and influenza? The Lancet 363: 234-236.

Weiss, R.A., and A.J. McMichael. 2004. Social and environmental risk factors in the emergence of infectious diseases. Nature Medicine 10: S70-S76.

Woo, P.C., S.K. Lau, and K.-Y. Yuen. 2006. Infectious diseases emerging from Chinese wet-markets: Zoonotic origins of severe respiratory viral infections. Current Opinion in Infectious Diseases 19: 401-407.

World Bank. 2020. World development indicators. Washington, DC: The World Bank.

Wu, T. 2020a. COVID-19, the Anthropocene, and the imperative of US-China cooperation. EcoHealth 17: 268-269.

$\mathrm{Wu}, \mathrm{T}$., and C. Perrings. 2018. The live poultry trade and the spread of highly pathogenic avian influenza: Regional differences 
between Europe, West Africa, and Southeast Asia. PLoS ONE 13: e0208197.

Wu, T., C. Perrings, A. Kinzig, J.P. Collins, B.A. Minteer, and P. Daszak. 2017. Economic growth, urbanization, globalization, and the risks of emerging infectious diseases in China: A review. Ambio 46: 18-29.

Wu, T., C. Perrings, C. Shang, J.P. Collins, P. Daszak, A. Kinzig, and B.A. Minteer. 2020. Protection of wetlands as a strategy for reducing the spread of avian influenza from migratory waterfowl. Ambio 49: 939-949.

Wu, W. 2020b. Coronavirus: China's Centres for Disease Control should have power to warn public, says country's leading expert. South China Morning Post.

Wuhan Bureau of Statistics. 2020. Wuhan Socioeconomic Development Statistical Bulletin 2019. Wuhan: Wuhan Bureau of Statistics.

Young, O.R., F. Berkhout, G.C. Gallopin, M.A. Janssen, E. Ostrom, and S. van der Leeuw. 2006. The globalization of socioecological systems: An agenda for scientific research. Global Environmental Change 16: 304-316.

Zhang, H., L. Wang, S. Lai, Z. Li, Q. Sun, and P. Zhang. 2017. Surveillance and early warning systems of infectious disease in China: From 2012 to 2014. International Journal of Health Planning and Management 32: 329-338.
Zhang, L., N. Hua, and S. Sun. 2008. Wildlife trade, consumption and conservation awareness in southwest China. Biodiversity and Conservation 17: 1493-1516.

Zhou, P., X.-L. Yang, X.-G. Wang, B. Hu, L. Zhang, W. Zhang, H.-R. $\mathrm{Si}$, Y. Zhu, et al. 2020. A pneumonia outbreak associated with a new coronavirus of probable bat origin. Nature 579: 270-273.

Zhu, Z., A. Zhang, and Y. Zhang. 2018. Connectivity of intercity passenger transportation in China: A multi-modal and network approach. Journal of Transport Geography 71: 263-276.

Publisher's Note Springer Nature remains neutral with regard to jurisdictional claims in published maps and institutional affiliations.

\section{AUTHOR BIOGRAPHY}

Tong Wu $(\bowtie)$ is a Research Scientist at the State Key Laboratory of Urban and Regional Ecology, Research Center for Eco-Environmental Sciences, Chinese Academy of Sciences. His research interests include ecological economics, environmental health, and conservation biology.

Address: State Key Laboratory of Urban and Regional Ecology, Research Center for Eco-Environmental Sciences, Chinese Academy of Sciences, 18 Shuangqing Road, Haidian District, Beijing 100085, China.

e-mail: tongwu15@outlook.com 